\title{
A STUDY OF THE METABOLISM OF ASTHMA*
}

\author{
EDWIN ZUGSMITH, M.D., ANd MAX KAHN, M.D., Ph.D. \\ PITTSBURGH \\ NEW YORK
}

The effects of asthma on the anabolism and katabolism of the human body should be considered from different points of view. The causative factor (for example, anaphylaxis, etc.) may induce certain pathochemical changes which lead to asthma as one of the results, and these pathochemical changes are the disturbing factors in the metabolism of these patients, or, again, the syndrome, asthma, may affect the metabolism of the patient by (for instance) depriving the blood of oxygen, or by affecting the nervous system, circulatory system, etc. When, therefore, results are reported of the metabolism findings in asthmatic individuals, discrimination should be used as to which factor is to be held responsible for these deviations from the normal chemical balance of the body.

Before discussing the experiments that we have performed in our study of this disease, we wish to review the literature that may be pertinent to this subject. We have found no report of a complete metabolism study of patients suffering from asthma. The effect of dyspnea on metabolism has, however, been investigated.

Senato ${ }^{1}$ has found that moderate respiratory impediment affects but little the nitrogen katabolism, sometimes augmenting it slightly, whereas if the dyspnea becomes very great, the increase of the nitrogen excretion is marked and may last several days after the disappearance of the dyspnea (Fraenkel, ${ }^{2}$ Fleischer and Penzoldt, ${ }^{3}$ Fraenkel and Geppert, ${ }^{4}$ Klemperer, ${ }^{5}$ Praussnitz, ${ }^{6}$ Araki $\left.{ }^{7}\right)$.

Colosanti is the only observer who comes to the opposite conclusion, and his reputation is such that his work cannot be slighted. Colosanti and Palamenti obstructed the breathing by chemical and by mechanical means, and found that the percentages of urea and nitrogen in the urine were both subnormal as long as the obstruction was main-

* Submitted for publication Feb. 19, 1918.

* From the Department of Laboratories, Beth Israel Hospital.

1. Senator: Arch. f. path. Anat. u. Physiol., 1868, 42, 1.

2. Frankel: Arch. f. path. Anat. u. Physiol., 1876, 57, 273.

3. Fleischer and Penzoldt: Arch. f. path. Anat. u. Physiol., 1882, 78, 210.

4. Fraenkel and Geppert: Ueber die Wirkungen der verdunnten Luft auf den Organ, 1883, p. 78.

5. Klemperer: Ztschr. f. klin. Med., 1889, 16, 584.

6. Praussnitz: Sitzungsb. d. Gesellsch. f. Morphol. u. Physiol. in München., $1890,5,70$.

7. Araki : Ztschr. f. physiol. Chem., 1891, 15, 335.

8. Colosanti and Palamanti: Maly's Jahresb. u. d. Fortschr. d. Thierchem., $1894,24,466$. 
tained, rising again when the impediment was removed. They also say that the secretion of urine ceased during dyspnea.

Matthes ${ }^{9}$ writes: "One must hesitate before accepting unqualifiedly their conclusions that the lessened supply of oxygen diminished the activity of the regressive metamorphoses of the organism."

We shall discuss the Colosanti results later.

It has been generally accepted by the German school that there is a breaking down of protein in dyspnea. Whether this is due to a breaking down of the body cells due to lack of oxygen (a theory suggested by Fränkel), or whether (as Klemperer asserts) the increased protein katabolism is due to a poison produced by the dyspnea, or whether (according to Praussnitz) the primary effect of the dyspnea is to break down the nonnitrogenous substances in the body, and only secondarily to augment the protein decomposition-is a much mooted point.

Saccone ${ }^{10}$ found that the restriction of respiration in a dog by the application of a Sayre corset caused an increased elimination of urinary phosphorus, which became normal only after two days.

It has been found by a number of observers that when tissue oxidation is lessened, due to dyspnea, unoxidized products may be eliminated in the urine, as, for example, lactic acid. Senator, ${ }^{1}$ for instance, found glucose in the urine of dogs with dyspnea, and Dastre ${ }^{11}$ found a hyperglycemia in similar conditions. It was proved by Hoppe-Seyler ${ }^{12}$ that the lactic acid excreted under these circumstances was paralactic acid; that is, ethylidene lactic acid.

Dyspnea may be induced by vagus paralysis. But it has been found by Rauber and $\mathrm{Voit}^{13}$ that the oxygen absorption and the carbon dioxid elimination were not changed in experimental section of both vagi. Von Maar, ${ }^{14}$ however, reported different results:

The absorption of oxygen increases considerably, and generally is doubled, in the lung whose vagus is cut, and it falls almost as much in the other lung. The excretion of carbon dioxid was affected in the same sense as the absorption of oxygen, but to a far less extent. Von Maar found that as soon as the other vagus was cut, the breathing of the two lungs became equalized. He exposed and scrutinized the lung during one experiment, and could see no change in the amount of blood that it contained, thus making it plain that the circulation had nothing to do with the changes observed. On the other hand, by compressing the left pulmonary artery, he did directly disturb the circulation through the lungs (Matthes ${ }^{\mathrm{ks}}$ ).

9. Matthes, M., in C. von Noorden's "Metabolism and Practical Medicine," $1907,2,331$.

10. Saccone: Ann. di med. nav., 1907, 13, (1), 573.

11. Dastre: De la Glycemie asphysique, Thèse de Paris, 1879.

12. Hoppe-Seyler: Ztschr. f. physiol. Chem., 1895, 20, 365.

13. Rauber and Voit: Sitzungsb. d. k. Akad. d. Wssensch., zu. München, 1868.

14. Von Maar: Skand. Arch. f. Physiol., 1902, 229.

15. Matthes: von Noorden: Metabolism and Practical Medicine, 1907, 2, 304. 
CASE 1.-History.-A married woman. aged 40, developed a severe attack of asthma when in midocean seven years previously, and continued to be afflicted in varying degrees of severity and almost without interruption until the present report. One maternal aunt was an asthmatic. As a child the patient had one or two attacks of oppressed breathing. History and family history are otherwise negative in so far as they have a bearing on the asthmatic state. Her condition at the time of the examination showed a normal blood pressure, and gave normal urinary findings on routine examination. There was a profuse expectoration of mucopus containing a great variety of bacteria, and there was considerable mucus in the stool. Roentgen-ray examination of the lungs had already shown an absence of any tuberculous lesion, but disclosed the fact that the larger bronchial tube walls were much hypertrophied-a result no doubt of the long continued effort at forced breathing.

Preliminary Laboratory Examinations.-The urine was light, amber, specific gravity 1.018, acid, containing no albumin, glucose or the acetone derivatives, showing a trace of indican. Microscopically, many squamous epithelial cells derived from the vulva were present.

Examination of the blood was negative.

The feces were yellow in color, of semisolid consistence, containing no blood, but rather excessive quantities of mucus which was microscopically negative.

Bacteriologic examination of the sputum showed the presence of staphylococcus, streptococcus, and Micrococcus catarrhalis.

The Wassermann test was negative (Dr. Bronfenbrenner).

Method of Procedure.-The patient was put on a Folin diet, which consists of : Whole milk, 500 c.c.

Cream (18-22 per cent. fat), 300 c.c.

Eggs (white and yolk), $450 \mathrm{gm}$.

Horlick's malted milk, $200 \mathrm{gm}$.

Sugar, $20 \mathrm{gm}$.

Sodium chlorid, $6 \mathrm{gm}$.

Water enough to make the whole up to 2 liters.

"The ingredients combine into a liquid mixture containing $119 \mathrm{gm}$. protein, and approximately $148 \mathrm{gm}$. fat and $225 \mathrm{gm}$. carbohydrates." (Folin.)

The patient was kept on this diet for three days. The twenty-four-hour urine collections were preserved with thymol. The daily intestinal evacuations were marked off by a capsule of carmin $(0.3 \mathrm{gm}$.).

The following methods were used for the analyses of the urine and feces: The nitrogen was estimated according to Kjeldahl, and the total sulphur by the Benedict $^{13}$ method; total and ethereal sulphates, by the Folin ${ }^{17}$ method; the inorganic sulphates were computed by subtracting the ethereal sulphates from the total sulphates; the "neutral" sulphur was computed by subtracting the total sulphate sulphur from the total sulphur. Urea was estimated by Benedict'ss method, ammonia and creatinin by Folin's ${ }^{19}$ methods, uric acid by the FolinShaffer ${ }^{20}$ method, purin bases by the Kruger-Schmidt ${ }^{21}$ method, phosphorus by Neumann's:2 method, calcium and magnesium by McCrudden's ${ }^{23}$ method.

16. Benedict: Jour. Biol. Chem., 1909, 6, 363.

17. Folin: Am. Jour. Physiol., 1905, 13, 51.

18. Benedict: Jour. Biol. Chem., 1911, 8, 455.

19. Folin: Am. Jour. Physiol., 1903, 8, 330.

20. Folin and Shaffer: Ztschr. f. physiol. Chem., 1901, 32, 552.

21. Kruger and Schmidt: See Hawk, Practical Physiol. Chem., Ed. 5, 1916, 513.

22. Neumann: Ztschr. f. physiol. Chem., 1904, 43, 45.

23. McCrudden : Jour. Biol. Chem., 1911, 10, 187. 
METABOLISM STUDIES

Study of the Nitrogen Metabolism.-The patient took in daily an average of $17.5 \mathrm{gm}$. nitrogen in her food. In the urine she voided daily an average of $11.4 \mathrm{gm}$. nitrogen, and in her feces, an average of $2.2 \mathrm{gm}$. nitrogen. There was thus left a positive balance of $3.9 \mathrm{gm}$. Nitrogen representing $33.15 \mathrm{gm}$. protein.

The nitrogen partition of the urine shows the following: The percentage excretion of urea, ammonia, and uric acid nitrogen is normal. There is a slight increase in the elimination of the creatinin and aminoacid nitrogen. The data for the nitrogen partitions are represented in Table 1 .

Study of the Sulphur Metabolism.-The patient took daily in her food an average of $3.2 \mathrm{gm}$. sulphur trioxid $\left(\mathrm{SO}_{3}\right)$ and voided in the urine daily an average of $2.4 \mathrm{gm}$. sulphur trioxid, and in the feces $0.93 \mathrm{gm}$., causing a negative balance of $0.13 \mathrm{gm}$. It thus seems that in this case the katabolism of the sulphur portion of the molecule does not go hand in hand with the nitrogen katabolism, for, whereas there was a positive average balance of $3.9 \mathrm{gm}$. nitrogen, the sulphur shows a loss. The sulphur partition in the urine is very interesting. There is an increase in the nonoxidized sulphur fraction (so-called "neutral sulphur"). This would be in harmony with the findings of Reale and Boeri, ${ }^{24}$ who observed that by inducing dyspnea in dogs by compression of the chest, there was a marked increase in the "neutral" sulphur fraction of the urine - even as high as 37.5 per cent. of the total sulphur.

The ethereal sulphates were not increased, showing that there was not present to any extent an intestinal putrefactive condition. Von Noorden ${ }^{25}$ found, in general, that there was no deviation from the normal in the limination of the conjugated sulphates in the urine by emphysematous subjects.

Since one of us is interested in the volatile sulphids eliminated in the urine, we determined that fraction in the urine was found that from 2 to 3 per cent. of the total sulphur was volatile sulphid. We made no attempt to identify which of the volatile sulphids were present. It would be interesting to analyze such urine for hydrogen sulphid, mercaptan, ethylsulphid, etc.

The ratio of nitrogen to sulphur was on the average of $11.5: 1$.

The data of the sulphur partition are given in Table 2 .

Study of the Mineral Metabolism. - As will be seen from the accompanying data on Table 3 , there was nothing strikingly abnormal

24. Reale and Boeri: Wien. med. Wchnschr., 1895.

25. Von Noorden: See Matthes, Footnote 15. 
TABLE 1.-Nitrogen Partition-

\begin{tabular}{|c|c|c|c|c|c|c|}
\hline \multirow[b]{2}{*}{ Day } & \multirow{2}{*}{$\begin{array}{l}\text { Volume } \\
\text { Urine, } \\
\text { C.c. }\end{array}$} & \multirow[b]{2}{*}{$\begin{array}{c}\text { Nitrogen } \\
\text { Gm. }\end{array}$} & \multicolumn{2}{|c|}{ Urea $\mathrm{N}$} & \multicolumn{2}{|c|}{ Ammonia $\mathrm{N}$} \\
\hline & & & $\begin{array}{l}\text { Per Cent. } \\
\text { 'Total } \mathbf{N}\end{array}$ & $\mathrm{Gm}$. & $\begin{array}{c}\text { Per Cent. } \\
\text { Total N }\end{array}$ & Gm. \\
\hline 1 & 1,070 & 12.3 & 82.7 & 10.1721 & 2.5 & 0.3074 \\
\hline 2 & 760 & 10.4 & 80.5 & 8.373 & 2.2 & 0.2288 \\
\hline 3 & 890 & 11.7 & 80.2 & 9.385 & 3.9 & 0.4563 \\
\hline Average & 906 & 11.4 & 81.1 & 9.2455 & 2.8 & 0.3192 \\
\hline
\end{tabular}

TABle 2.-Sulphur Partition of Urine, Case 1

\begin{tabular}{|c|c|c|c|c|c|c|c|c|c|}
\hline \multirow[b]{2}{*}{ Day } & \multirow[b]{2}{*}{$\begin{array}{l}\text { Total } \\
\text { S as } \\
\mathrm{SOs}^{2} \\
\mathrm{Gm} .\end{array}$} & \multicolumn{2}{|c|}{ Inorganie $\mathrm{SO}_{3}$} & \multicolumn{2}{|c|}{ Ethereal $\mathrm{SO}_{3}$} & \multicolumn{3}{|c|}{ Neutral $\mathrm{S}$ as $\mathrm{SO}_{3}$} & \multirow[b]{2}{*}{$\begin{array}{c}\text { N:S } \\
\text { Ratio }\end{array}$} \\
\hline & & $\begin{array}{l}\text { Per } \\
\text { Cent. } \\
\text { Total } \\
\mathrm{SO}_{3}\end{array}$ & $\mathrm{Gm}$ & $\begin{array}{l}\text { Per } \\
\text { Cent. } \\
\text { Total } \\
\mathrm{SO}_{3}\end{array}$ & $\mathrm{Gm}$. & $\begin{array}{l}\text { Per } \\
\text { Cent. } \\
\text { Total } \\
\mathrm{SO}_{3}\end{array}$ & $\mathrm{Gm}$ & \begin{tabular}{|} 
Volatile $\mathbf{S}$ \\
Portion, \\
per Cent. of \\
Total \\
$\mathrm{SO}_{3}$
\end{tabular} & \\
\hline 1 & 2.7 & 68.8 & 1.8576 & 12.8 & 0.3456 & 18.4 & 0.4968 & 2.4 & $11.3: 1$ \\
\hline 2 & 2.1 & 67.4 & 1.4254 & 14.9 & 0.3129 & 17.7 & 0.3727 & 2.35 & $12.2: 1$ \\
\hline 3 & 2.6 & 66.7 & 1.7342 & 14.2 & 0.3692 & 19.1 & 0.4986 & 2.97 & $11.2: 1$ \\
\hline Aver. & 2.4 & 67.6 & 1.6224 & 13.9 & 0.3336 & 18.4 & 0.4416 & 2.57 & 11.5:1 \\
\hline
\end{tabular}

Table 3.-Mineral Excretion in the Urine and Feces, Case 1

\begin{tabular}{|c|c|c|c|c|c|c|c|}
\hline \multirow[b]{2}{*}{ Day } & \multicolumn{2}{|c|}{ Phosphorus Pentoxid } & \multicolumn{2}{|c|}{ Calcium Oxid } & \multicolumn{2}{|c|}{ Magnesium Oxid } & \multirow{2}{*}{$\begin{array}{c}\text { Chlorin } \\
\text { in } \\
\text { Urine, } \\
\text { Gm. }\end{array}$} \\
\hline & $\begin{array}{l}\text { Urine, } \\
\text { Gm. }\end{array}$ & $\begin{array}{c}\text { Feces, } \\
\text { Gm. }\end{array}$ & $\begin{array}{l}\text { Urine, } \\
\text { Gm. }\end{array}$ & $\begin{array}{c}\text { Feces, } \\
\text { Gm. }\end{array}$ & $\begin{array}{l}\text { Urine, } \\
\text { Gm. }\end{array}$ & $\begin{array}{l}\text { Feces, } \\
\text { Gm. }\end{array}$ & \\
\hline 1 & 2.9 & 1.8 & 06 & 1.61 & 0.92 & 0.57 & 5.7 \\
\hline 2 & 3.1 & 0.8 & 0.67 & 1.59 & 0.87 & 0.32 & 5.2 \\
\hline 3 & 2.7 & 1.9 & 0.72 & 1.82 & 0.91 & 0.42 & 6.3 \\
\hline Average & 2.9 & 1.3 & $\underbrace{0.66}$ & 1.67 & $\underbrace{0.9}$ & 0.43 & 5.7 \\
\hline Total & \multicolumn{2}{|c|}{4.2} & \multicolumn{2}{|r|}{2.33} & \multicolumn{2}{|c|}{1.33} & \\
\hline
\end{tabular}

in the elimination of phosphorus, calcium and magnesium in the urine and feces. There was an average daily positive balance of $0.9 \mathrm{gm}$. phosphorus pentoxid $\left(\mathrm{P}_{2} \mathrm{O}_{5}\right), 0.36 \mathrm{gm}$. calcium oxid $(\mathrm{CaO}), 0.12 \mathrm{gm}$. magnesium oxid ( $\mathrm{MgO})$. The French school of physicians have described phenomena of marked demineralization, that is, loss of calcium oxid, phosphorus pentoxid and magnesium oxid in pulmonary 
-OF URINe. CASE 1

\begin{tabular}{|c|c|c|c|c|c|c|c|c|}
\hline $\begin{array}{l}\text { Per Cent. } \\
\text { Total N }\end{array}$ & Gm. & $\begin{array}{l}\text { Per Cent. } \\
\text { Total N }\end{array}$ & Gm. & $\begin{array}{l}\text { Per Cent. } \\
\text { Total N }\end{array}$ & Gm. & $\begin{array}{l}\text { Per Cent. } \\
\text { Total N }\end{array}$ & Gm. & $\begin{array}{l}\text { Per Cent. } \\
\text { Total N }\end{array}$ \\
\hline 2.1 & 0.2583 & 2.7 & 0.3321 & 2.2 & 0.2706 & 5.7 & 0.7011 & 0.2 \\
\hline 4.3 & 0.5031 & 2.8 & 0.3276 & 1.9 & $0.2 \cdot 23$ & 6.8 & 0.6786 & 1.1 \\
\hline 3.3 & 0.3762 & 2.4 & 0.2736 & 2.06 & 0.2348 & 5.6 & 0.6612 & 1.5 \\
\hline
\end{tabular}

Table 4.-Balance Sheet, Case 1

\begin{tabular}{|c|c|c|c|c|c|c|c|c|}
\hline & Nitrogen & $\begin{array}{l}\text { Sulphur } \\
\text { Trioxid }\end{array}$ & \multicolumn{2}{|c|}{$\begin{array}{l}\text { Phosphoras } \\
\text { Pentoxid }\end{array}$} & \multicolumn{2}{|c|}{$\begin{array}{l}\text { Calcium } \\
\text { Oxid }\end{array}$} & \multicolumn{2}{|c|}{$\begin{array}{l}\text { Magnesium } \\
\text { Oxid }\end{array}$} \\
\hline & $\begin{array}{l}\text { Feces, Urine, } \\
\text { Gm. Gm. }\end{array}$ & $\begin{array}{c}\text { Feces, Urine, } \\
\text { Gm. }\end{array}$ & $\begin{array}{l}\text { Feces, } \\
\text { Gm. }\end{array}$ & $\begin{array}{l}\text { Urine, } \\
\text { Gm. }\end{array}$ & $\begin{array}{l}\text { Feces, } \\
\text { Gm. }\end{array}$ & $\begin{array}{l}\text { Urine, } \\
\text { Gm. }\end{array}$ & $\begin{array}{l}\text { Feces, } \\
\text { Gm. }\end{array}$ & $\begin{array}{l}\text { Urine, } \\
\text { Gm. }\end{array}$ \\
\hline Aver. daily intake... & 17.5 & 3.2 & \multicolumn{2}{|c|}{5.1} & \multicolumn{2}{|c|}{2.7} & \multicolumn{2}{|c|}{1.4} \\
\hline $\begin{array}{r}\text { Output first day...... } \\
\text { Total............ }\end{array}$ & $12.3{ }_{14.5}^{2.2}$ & $2.73 .5^{0.8}$ & \multicolumn{2}{|c|}{${ }_{4.1}^{1.2}$} & \multicolumn{2}{|c|}{$0.6 \underbrace{}_{2.21^{1.61}}$} & \multicolumn{2}{|c|}{${ }_{1.49}^{0.92} 0.57$} \\
\hline $\begin{array}{r}\text { Output second day.. } \\
\text { Total............. }\end{array}$ & ${ }_{13.1}^{10.4}$ & $2.12 .8^{0.7}$ & \multicolumn{2}{|c|}{$3.13 .9^{0.8}$} & \multicolumn{2}{|c|}{$0.676_{2.26}^{1.59}$} & \multicolumn{2}{|c|}{${ }_{1.19}^{0.87} 0.32$} \\
\hline $\begin{array}{l}\text { Output third day... } \\
\text { Total........... }\end{array}$ & ${ }_{13.5}^{11.7} 1.8$ & $3.6^{2.9^{1.3}}$ & \multicolumn{2}{|c|}{$2.7{ }_{4.6}^{1.9}$} & \multicolumn{2}{|c|}{$\frac{0.72}{2.54}$} & \multicolumn{2}{|c|}{$\underbrace{0.91}_{1.33} 0.42$} \\
\hline $\begin{array}{l}\text { Average output...... } \\
\text { Total............ }\end{array}$ & ${ }_{13.6^{2.2}}^{11.4}$ & $2.43 .33^{0.93}$ & 2.9 & $2^{1.3}$ & $\begin{array}{r}0.66 \\
\quad 2\end{array}$ & 1.67 & 0.9 & 0.43 \\
\hline $\begin{array}{l}\text { Total intake, three } \\
\text { days....................... }\end{array}$ & 52.5 & 9.6 & \multicolumn{2}{|c|}{15.3} & \multicolumn{2}{|c|}{8.10} & \multicolumn{2}{|c|}{4.2} \\
\hline $\begin{array}{l}\text { Total output, three } \\
\text { days................. }\end{array}$ & 41.1 & 10.2 & \multicolumn{2}{|c|}{12.6} & \multicolumn{2}{|c|}{7.01} & \multicolumn{2}{|c|}{4.01} \\
\hline $\begin{array}{c}\text { Balance after three } \\
\text { days................ }\end{array}$ & +11.4 & -0.6 & \multicolumn{2}{|c|}{+2.7} & \multicolumn{2}{|c|}{+1.09} & +0 & \\
\hline $\begin{array}{l}\text { Average daily bal- } \\
\text { ance.............. }\end{array}$ & +3.8 & -0.2 & +0 & & +0 & & +0. & \\
\hline
\end{tabular}

phthisis. This patient has no evidence whatever of tuberculosis. As far as we are aware, the mineral metabolism of asthma has never been previously studied.

In Table 4 is given a balance sheet of the intake and output of nitrogen, sulphur trioxid, phosphorus pentoxid, calcium oxid and magnesium oxid. The average intake of the three days is given. The output data are given in their daily quantities.

CASE 2--History.-A young woman, aged 29, married, with a healthy child. Her family history is negative. Her past history shows that when a child she had several attacks of pleurisy and pneumonia. During the past few years she complains of shortness of breath, of occasional typical asthmatic seizures, which pass off after several hours. Her heart and kidneys are normal. A slight degree of emphysema is present. 
The urine examination is negative; specific gravity, 1.016. Examination of the feces is negative. The sputum shows many streptococci, pneumococci and pus cells. Negative for tubercle bacilli after guinea-pig inoculation. The blood count shows hemoglobin, 90 per cent.; red blood cells, 4,200,000; white blood cells, 10,200; polynuclears, 62 per cent.; mononuclears, 35 per cent.; eosinophils, 3.0 per cent. The Wassermann test is negative.

This patient was also kept on a Folin diet for three days, and her metabolism was studied on the plan described under Case 1.

Study of the Nitrogen Metabolism.-From the data of Table 8 it will be seen that the patient took in daily an average of $18.8 \mathrm{gm}$. of

TABLE 5.-URINARY Nitrogen-

\begin{tabular}{|c|c|c|c|c|c|c|}
\hline \multirow[b]{2}{*}{ Day } & \multirow{2}{*}{$\begin{array}{c}\text { Volume } \\
\text { Urine, } \\
\text { C.e. }\end{array}$} & \multirow[b]{2}{*}{ Nitrogen } & \multicolumn{2}{|c|}{ Urea $\mathbf{N}$} & \multicolumn{2}{|c|}{ Ammonia $\mathrm{N}$} \\
\hline & & & $\begin{array}{l}\text { Per Cent. } \\
\text { Total N }\end{array}$ & $\mathrm{Gm}$. & $\begin{array}{l}\text { Per Cent. } \\
\text { Total N }\end{array}$ & Gm. \\
\hline 1 & 1,520 & 14.94 & 85.5 & 12.7737 & 4.7 & 0.7022 \\
\hline 2 & 1,725 & 14.82 & 86.4 & 12.805 & 4.1 & 0.6076 \\
\hline 3 & 1,650 & 14.35 & 84.2 & 12.1827 & 3.5 & 0.5022 \\
\hline Average & 1,631 & 14.703 & 85.3 & 12.5391 & 4.1 & 0.6027 \\
\hline
\end{tabular}

Table 6.-Urinary Sulphur Partition, Case 2

\begin{tabular}{|c|c|c|c|c|c|c|c|c|c|}
\hline \multirow[b]{2}{*}{ Day } & \multirow[b]{2}{*}{$\begin{array}{l}\text { Total } \\
\text { S as } \\
\mathrm{SO}_{3} \\
\mathrm{Gm} .\end{array}$} & \multicolumn{2}{|c|}{ Inorganic $\mathrm{SO}_{3}$} & \multicolumn{2}{|c|}{ Ethereal $\mathrm{SO}_{3}$} & \multicolumn{3}{|c|}{ Neutral $\mathrm{S}$ as $\mathrm{SO}_{3}$} & \multirow[b]{2}{*}{$\begin{array}{l}\text { N:S } \\
\text { Ratio }\end{array}$} \\
\hline & & $\begin{array}{l}\text { Per } \\
\text { Cent. } \\
\text { Total } \\
\mathrm{SO}_{3}\end{array}$ & Gm. & $\begin{array}{l}\text { Per } \\
\text { Cent. } \\
\text { Total } \\
\mathrm{SO}_{3}\end{array}$ & $\mathrm{Gm}$. & $\begin{array}{l}\text { Per } \\
\text { Cent. } \\
\text { Total } \\
\mathrm{SO}_{3}\end{array}$ & Gm. & $\begin{array}{c}\text { Volatile S } \\
\text { Portion, } \\
\text { per Cent. of } \\
\text { Total } \\
\text { SOs }\end{array}$ & \\
\hline 1 & 3.87 & 52,4 & 2.0278 & 29.7 & 1.1494 & 17.9 & 0.6917 & 2.15 & $9.9: 1$ \\
\hline 2 & 3.81 & 54.1 & 2.0558 & 26.8 & 1.1211 & 19.1 & 0.5677 & 3.22 & $9.5: 1$ \\
\hline 3 & 3.72 & 56.0 & 2.0832 & 27.5 & 0.8230 & 16.5 & 0.6138 & 2.17 & $9.8: 1$ \\
\hline Aver. & 3.8 & 54.1 & 2.0558 & 28.0 & 1.0640 & 17.8 & 0.6764 & 2.51 & $9.7: 1$ \\
\hline
\end{tabular}

Table 7.-Mineral Excretion in Urine and Feces, Case 2

\begin{tabular}{|c|c|c|c|c|c|c|}
\hline \multirow[b]{2}{*}{ Day } & \multicolumn{2}{|c|}{ Phosphorus Pentoxid } & \multicolumn{2}{|c|}{ Calcium Oxid } & \multicolumn{2}{|c|}{ Magnesium Oxid } \\
\hline & $\begin{array}{c}\text { Urine, } \\
\text { Gm. }\end{array}$ & $\begin{array}{l}\text { Feces, } \\
\text { Gm. }\end{array}$ & $\begin{array}{l}\text { Urine, } \\
\text { Gm. }\end{array}$ & $\begin{array}{c}\text { Feces, } \\
\text { Gm. }\end{array}$ & $\begin{array}{l}\text { Urine, } \\
\text { Gm. }\end{array}$ & $\begin{array}{c}\text { Feces, } \\
\text { Gm. }\end{array}$ \\
\hline 1 & 3.21 & 1.07 & 0.92 & 2.2 & 0.35 & 0.09 \\
\hline 2 & 3.32 & 1.12 & 0.85 & 2.5 & 0.32 & 0.11 \\
\hline 3 & 2.95 & 1.70 & 0.94 & 2.4 & 0.33 & 0.12 \\
\hline Average & 3.19 & 1.29 & 0.903 & 2.3 & 0.33 & 0.106 \\
\hline Total & \multicolumn{2}{|c|}{4.48} & \multicolumn{2}{|c|}{3.208} & \multicolumn{2}{|c|}{0.436} \\
\hline
\end{tabular}


nitrogen and excreted daily an average of $14.703 \mathrm{gm}$. nitrogen in the urine and $2.83 \mathrm{gm}$. in the feces, showing a positive average balance of $1.267 \mathrm{gm}$. nitrogen, or $7.918 \mathrm{gm}$. protein. The nitrogen partition was normal, except, perhaps, that there is a slight deduction in the creatinin excretion. The urea nitrogen, ammonia nitrogen, purin base and uric acid nitrogen and amino-acid nitrogen fractions are normal.

Study of the Sulphur Metabolism.-It will be seen (Table 8) that the patient took in a daily average of $4.785 \mathrm{gm}$. sulphur trioxid in her

-Partition, Case 2

\begin{tabular}{|c|c|c|c|c|c|c|c|c|}
\hline \multicolumn{2}{|c|}{ Amino-Acid N } & \multicolumn{2}{|c|}{ Uric Acid $\mathbf{N}$} & \multicolumn{2}{|c|}{ Purin Base N } & \multicolumn{2}{|c|}{ Creatinin $\mathbf{N}$} & \multirow{2}{*}{ 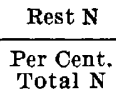 } \\
\hline $\begin{array}{l}\text { Per Cent. } \\
\text { Total N }\end{array}$ & $\mathrm{Gm}$. & $\begin{array}{l}\text { Per Cent. } \\
\text { Total N }\end{array}$ & $\mathrm{Gm}$. & $\begin{array}{l}\text { Per Cent. } \\
\text { Total N }\end{array}$ & $\mathrm{Gm}$. & $\begin{array}{l}\text { Per Cent. } \\
\text { Total N }\end{array}$ & $\mathrm{Gm}$. & \\
\hline 1.7 & 0.2539 & 2.0 & 0.2988 & 2.1 & 0.3137 & 2.2 & 0.3298 & 1.8 \\
\hline 2.1 & 0.3112 & 1.9 & 0.2816 & 2.5 & 0.3705 & 2.7 & 0.4001 & 0.4 \\
\hline 1.9 & 0.2726 & 17. & 0.2439 & 1.9 & 0,2726 & 3.2 & 0.4592 & 2.6 \\
\hline 1.9 & 0.2793 & 1.86 & 0.2734 & 2.1 & 0.3087 & 2.7 & 0.3569 & 1.6 \\
\hline
\end{tabular}

Table 8.-Balance Sheet, Case 2

\begin{tabular}{|c|c|c|c|c|c|c|}
\hline & Nitrogen & $\begin{array}{l}\text { Sulphur } \\
\text { Trioxid }\end{array}$ & $\begin{array}{l}\text { Phosphorus } \\
\text { Pentoxid }\end{array}$ & $\begin{array}{l}\text { Oalcium } \\
\text { Oxid }\end{array}$ & $\underset{\text { Oxid }}{\text { Magnesium }}$ & Chlorin \\
\hline & $\begin{array}{l}\text { Urine, Feces, } \\
\text { Gm. Gm. }\end{array}$ & $\begin{array}{l}\text { Urine, Feces, } \\
\text { Gm. Gm. }\end{array}$ & $\begin{array}{cc}\text { Urine, Feces, } \\
\text { Gm. }\end{array}$ & $\begin{array}{l}\text { Urine, Feces, } \\
\text { Gm. Gm. }\end{array}$ & $\begin{array}{cc}\text { Urine, } & \text { Feces, } \\
\text { Gm. } & \text { Gm. }\end{array}$ & $\begin{array}{l}\text { Urine, } \\
\text { Gm. }\end{array}$ \\
\hline Aver. daily intake.. & 18.8 & 4.785 & 4.91 & 3.25 & 0.46 & 6.37 \\
\hline $\begin{array}{l}\text { Output first day.... } \\
\text { Total.......... }\end{array}$ & ${ }_{17.31}^{2.37}$ & $3.872^{0.65}$ & $3.214_{4.28^{1.07}}$ & $0.922^{2.2}$ & $0.350^{0.44}$ & 6.14 \\
\hline $\begin{array}{l}\text { Output second day. } \\
\text { Total........... }\end{array}$ & ${ }^{14.82} 17.38^{2.56}$ & $3.8148^{0.67}$ & $3.324_{4.44^{1.12}}$ & $3.35^{2.5}$ & $0.320^{0.11}$ & 6.25 \\
\hline $\begin{array}{l}\text { Output third day... } \\
\text { Total........... }\end{array}$ & $14.355^{2.74}$ & $3.724 .44^{0.72}$ & $2.954 .65^{1.70}$ & $0.944_{3.34^{2.4}}$ & $0.335^{0.12}$ & 6.03 \\
\hline $\begin{array}{r}\text { Average output.... } \\
\text { Total........... }\end{array}$ & $\begin{array}{c}14.703 \quad 2.83 \\
17.533\end{array}$ & $3.84 .48^{0.68}$ & $3.194 .48^{1.29}$ & ${ }_{3.208^{2.3}}^{0.903}$ & $\mid \begin{array}{cc}0.33 & \mathbf{0 . 1 0 6} \\
0.436\end{array}$ & 6.14 \\
\hline $\begin{array}{l}\text { Total intake, three } \\
\text { days................. }\end{array}$ & 56.4 & 14.355 & 14.73 & 9.75 & 1.38 & \\
\hline $\begin{array}{l}\text { Total output, three } \\
\text { days.............. }\end{array}$ & 52.599 & 13.44 & 13.44 & 9.609 & 1.308 & \\
\hline $\begin{array}{l}\text { Balance after three } \\
\text { days.............. }\end{array}$ & +3.601 & +0.915 & +1.29 & +0.141 & +0.072 & \\
\hline $\begin{array}{l}\text { Average daily bal- } \\
\text { ance............. }\end{array}$ & +1.267 & +0.305 & +0.43 & +0.047 & +0.024 & \\
\hline
\end{tabular}

food, and that she eliminated a daily average of $3.8 \mathrm{gm}$. sulphur trioxid in the urine and $0.68 \mathrm{gm}$. sulphur trioxid in the feces, leaving a daily positive balance of $0.305 \mathrm{gm}$. sulphur trioxid.

The urinary sulphur partition (Table 6) is interesting. The excretion of ethereal sulphates is increased, the figures being almost twice 
the quantities voided in Case 1 . It is interesting to note here that Patient 1 was accustomed to make rectal lavages and keep her bowels generally well evacuated. This patient (Case 2) is suffering from some intestinal stasis.

The neutral sulphur fraction is increased also in this patient, showing some condition of suboxidation. The volatile sulphid excretion is 2.51 per cent. of the total sulphur voided in the urine.

The $\mathrm{N}: \mathrm{S}$ ratio is $9.7: 1$.

The mineral metabolism shows an average daily positive balance of $0.43 \mathrm{gm}$. phosphorus pentoxid, $0.047 \mathrm{gm}$. calcium oxid and $0.024 \mathrm{gm}$. magnesium oxid (Table 8 ). The excretion of phosphorus pentoxid, calcium oxid and magnesium oxid (Table 7 ) is normal.

\section{GENERAL DISCUSSION}

Asthmatic individuals seem to suffer from a condition of tissue suboxidation. Whether this is due to the lack of oxygen induced by the functional failure of the pulmonary system, or whether the suboxidation is the result of the causative factor of the disease and is, perhaps, the etiologic factor in the production of the spasmodic seizure, cannot, of course, be at the present time decided. If it were possible to study the metabolism of a patient who did not suffer from asthma, but who had the etiologic factors present that may induce asthma, as, for example, an anaphylactic state that is present without the asthma, this point may be cleared up. The neutral sulphur ${ }^{26}$ fraction (consisting of the various unoxidized sulphur derivatives, like taturine, taurocarbamic acid, cystin, sulphocyanates, the oxyproteic and uroferric acid, the volatile sulphids, etc.) increase shows this lack of oxidation. This seems to agree with the findings of various observers who noticed a decrease of tissue oxidation in dyspneic animals.

We find also that the creatinin output is low, thus indicating a lessened tissue oxidation, for, according to Folin ${ }^{27}$ and others, the creatinin output depends only on the endogenous katabolism of the body.

While we did not notice that there was a lessened excretion of urea in urine, we found that the observation of Colosanti that there was a decrease in tissue breakdown during dyspnea, held true in human beings suffering from asthma. It is not true, however, that secretion of urine stops during the dyspneic attack, for in one case the secretion of urine seemed to be stimulated during the spasm, at least the patient voided urine frequently.

26. Kahn: Urinary Volatile Sulphids. To be published.

27. Folin: Am. Jour. Physiol., 1905, 13, 45. 